Ivan Markešić, Zagreb

\title{
O ČOVJEKU, ZNANSTVENIKU I UČITELJU AKADEMIKU IVANU CVITKOVIĆU, SOCIOLOGU RELIGIJE, U ČAST
}

Nije lako govoriti o ljudima koje osobno poznajete, o ljudima koje cijenite i poštujete, svejedno je li riječ o njihovim uspjesima, usponima ili pak o njihovim neuspjesima, gubitcima, stradanjima (fizičkim ili političkim). O njima nije lako govoriti ne zato što to ne bi bilo moguće uraditi, nego zato što uvijek postoji bojazan da bi se nešto vrijedno moglo ispustiti, zaboraviti, ne spomenuti. Posebno ako su vam ti ljudi u životu puno pomogli, a nisu morali, kao što je to bio slučaj profesora Cvitkovića i mene. No, unatoč svemu tomu, ili upravo zbog toga, osvrnut ću se na njegovo za naše prilike uistinu velebno djelo, na njegov prinos suvremenoj sociologiji religije u Bosni i Hercegovini, ali i u njezinu okruženju. Taj svoj govor o čovjeku, prijatelju, znanstveniku i učitelju počet ću riječima jednog od najutjecajnijih sociologa 20. stoljeća, riječima židovskoga sociologa njemačkog podrijetla s britanskim državljanstvom Norberta Eliasa (22. 6. 1897. - 1. 8. 1990.) koji na početku svoje knjige Studije o Nijemcima. Borbe za moć i razvoj habitusa u 19. i 20. stoljeću kaže sljedeće: "Iza ovih ovdje objavljenih istraživanja nalazi se - napola skriven - očevidac koji je gotovo 90 godina neprekidno pratio tijek zbivanja. Međutim, slika koju si on kao osobno pogođeni stvara o tim događajima, uobičajeno je i na karakterističan način različita od slike koju o tim događajima $\mathrm{s}$ rezervom i s distance stvara istraživač. A kao primjer neka posluži kamera s kojom je moguće objektiv namjestiti na različite distance - bliska, srednja te velika udaljenost. Slično vrijedi i za pogled onoga tko je sudionik zbivanja i onoga tko je istraživač” (Elias 2005: 7).

Slično bi se moglo kazati i za akademika Ivana Cvitkovića, najvećeg i najpoznatijeg bosanskohercegovačkoga sociologa religije. Analizirajući njegovo cjelokupno socioreligijsko djelo s pravom se može reći da se iza (pod njegovim imenom) objavljenih radova skriva očevidac koji je tijekom druge polovice 20. i prve polovice 21. stoljeća istodobno pratio, znanstveno propitivao i brižno analizirao procese društvenih, političkih, kulturnih, religijskih i inih zbivanja kako u Bosni i Hercegovini tako i u njezinu okruženju. A bilo je to 
razdoblje u kojemu je sociologija religije, u kojoj su se zrcalile sve društvene mijene i svi društveni procesi toga vremena, doživjela velike uspone i svoj puni procvat. U tome smislu Cvitkovićeve biografija i bibliografija usko su isprepletene s društvenim, političkim, ekonomskim i kulturnim previranjima ove faze bosanskohercegovačke i ondašnje jugoslavenske povijesti. Stoga je njegovu biobibliografiju nemoguće promatrati izvan okvira spomenutih procesa kako bivšega jugoslavenskog društva tako i sadašnjih postjugoslavenskih društava, jer on društva kao i same znanosti promatra kao "historijske procese" i na njih istodobno reagira ne pitajući (uvijek) koje značenje ti procesi imaju za nas, nego kao distancirani promatrač - slijedeći Eliasa - traži odgovor na pitanje: što je imanentni mehanizam tih događaja? (Elias 2003: 196)

Iako će i drugi u svojim prilozima spomenuti osnovne podatke iz Cvitkovićeve biobibliografije, ja ću tome dijelu posvetiti dužnu pažnju, jer podneblje iz kojega netko potječe, vrijeme u kojem se u tome podneblju rađa, prirodni, obiteljski i širi socijalni okoliš u kojem odrasta i razvija se u bitnome određuju budućnost svakoga od nas, pa tako je određivalo i budućnost akademika Ivana Cvitkovića.

Ivan Cvitković rodio se u Mostaru, petoga dana petoga mjeseca još uvijek ratne 1945. godine, dakle tri dana prije (službenoga) završetka Drugoga svjetskog rata, odnosno tri dana prije službenoga početka mira u Europi. Zahvaljujući mjestu rođenja, kao i mjestu odrastanja - pitoresknome mjestu Ilići na izvoru rijeke Radobolje ispod brda Mikuljače, u Mostaru je završio osnovnu školu i srednju Učiteljsku školu, potom u Sarajevu studij sociologije na Fakultetu političkih nauka (1967), zatim poslijediplomski studij "Teorije ateizma i religije" na Fakultetu političkih znanosti u Zagrebu. Na istome fakultetu magistrirao je 1974. godine radom Katolička crkva i omladina u urbanim sredinama Bosne, da bi 1978. na Fakultetu za sociologiju, novinarstvo i političke znanosti u Ljubljani doktorirao radom Marksistička misao i religija (kritika teološke kritike odnosa marksizma i socijalizma prema religiji).

Početak pohađanja poslijediplomskoga studija bila je važna stepenica da bi se u nastavnom i znanstvenom polju moglo ići dalje i napredovati pa je Cvitković u razdoblju od 1972. do 1980. bio asistent na Fakultetu političkih nauka u Sarajevu, dakle u isto vrijeme kada sam i ja na tome fakultetu pohađao studij sociologije (1973-1978) i kada sam ga i upoznao kao profesora; što znači da moje poznanstvo s njim traje već gotovo pola vijeka. Na istome fakultetu Cvitković će biti docent (1980-1986), izvanredni (1986-1989) te redoviti profesor (1989-2012). Uz napomenu da je kratko vrijeme od 1989. do 1990. - do početka demokratskih promjena u bosanskohercegovačkome 
društvu - radio kao i ja u Institutu za proučavanje nacionalnih odnosa koji će prerasti u Institut za društvena istraživanja Sarajevo.

Od 1974., dakle od vremena kada je postao asistent pa do danas, objavio je ukupno 36 vlastitih knjiga $^{1}$ po čijim naslovima prepoznajemo kojim se sve temama bavio.

${ }^{1}$ Knjige koje je objavio akademik Cvitković u razdoblju od 1974. do danas, do kraja siječnja 2020.

1. Cvitković, Ivan (2019), Religija u raljama politike, Djela, knj. LXXXVIII, Odjeljenje društvenih nauka, knj. 47, Akademija nauka i umjetnosti Bosne i Hercegovine, Sarajevo, ISBN 978-9926-410-35-3, 227 str.

2. Cvitković, Ivan (2017), Sociološki pogledi na naciju i religiju III, Štamparija Fojnica, Fojnica, ISBN 978-9958-17-101-7, 423 str.

3. Cvitković, Ivan (2017), Ganga: pjesma o životu u Hercegovini (Sociologijske marginalije o gangi), Editio Civitas, knj. 28, University press / Plejada, Sarajevo / Zagreb, ISBN 978-9958-673-54-2 i 978-953-7782-59-7, 195 str.

4. Cvitković, Ivan (2016), Religija u zrcalu teorija, Centar za empirijsko istraživanje religije - CEIR, Sarajevo, ISBN 978-9958-1981-7-5, 440 str.

5. Cvitković, Ivan (2014), Sociologija obreda, Edicija Memoria Mundi, Nacionalna i univerzitetska biblioteka Bosne i Hercegovine, Sarajevo, ISBN 978-9958-500-67-1, 390 str.

6. Cvitković, Ivan (2013), Encountering others: religious and confessional identities in Bosnia and Herzegovina, JUNIR, Niš, ISBN 978-86-86957-14-6, 110 str.

7. Cvitković, Ivan (2012), Sociološki pogledi na naciju i religiju II, Centar za empirijska istraživanja religije u Bosni i Hercegovini, Sarajevo, ISBN 978-9958-1981-0-6, 390 str.

8. Cvitković, Ivan (2011), Moj susjed musliman, Školska knjiga, Zagreb, ISBN 978-9530-61933-3, 299 str.

9. Cvitković, Ivan (2010), Religije suvremenoga svijeta, 4. dopunjeno izd., DES, Sarajevo, ISBN 978-9958-28-017-7, 363 str.

10. Cvitković, Ivan (2007), Sociologija religije, 4. izd., DES, Sarajevo, 443 str.

11. Cvitković, Ivan (2007), Socijalna naučavanja u religijama, Edicija Memoria Mundi, Nacionalna i univerzitetska biblioteka Bosne i Hercegovine, Sarajevo, ISBN 9789958-500-30-5, 330 str.

12. Cvitković, Ivan (2006), Hrvatski identitet u Bosni i Hercegovini: Hrvati između nacionalnog $i$ građanskog, Synopsis, Zagreb / Sarajevo, ISBN 953-7035-17-4, 316 str.

13. Cvitković, Ivan (2005), Religije suvremenoga svijeta, 3. izd., DES, Sarajevo, ISBN 9958-728-70-2, 333 str.

14. Cvitković, Ivan (2005), Sociološki pogledi na naciju i religiju, DES, Sarajevo, ISBN 9958-728-69-9, 345 str.

15. Cvitković, Ivan (2004), Sociologija religije, 3. izd., DES, Sarajevo, 443 str.

16. Cvitković, Ivan (2004), Konfesija u ratu, Interreligijska služba "Oči u oči” / Svjetlo riječi, Sarajevo / Zagreb, ISBN 9958-741-33-4 (Sarajevo) i 953-7091-15-5 (Zagreb), 223 str. (Godišnja nagrada Fakulteta političkih nauka za najbolju knjigu u 2004. godini)

17. Cvitković, Ivan (2002), Religije suvremenoga svijeta, 2. izd., DES, Sarajevo, ISBN 9958-728-37-0, 350 str.

18. Cvitković, Ivan (2001), Sociologija spoznaje, DES, Sarajevo, ISBN 9958-728-29-X, 279 str. 
U ovome mom kratkom prikazu njegova rada nemoguće je osvrnuti se na svaku od tih knjiga. No, bit ću toliko osoban i slobodan izabrati one za koje držim da su svojim sadržajem i svojim porukama toliko "izazovne" da su mogle mijenjati i da su mijenjale shvaćanja o postojećoj društvenoj i sociore-

19. Cvitković, Ivan (1999), Religije suvremenoga svijeta, 1. izd., Fakultet političkih nauka / Svjetska konferencija religija za mir, Sarajevo, ISBN 9958-9476-1-7, 294 str.

20. Cvitković, Ivan (1997), Društvena misao u svetim spisima, 1. izd., vlast. nakl., Mostar / Sarajevo, 195 str.

21. Cvitković, Ivan (1996), Sociologija religije, Edicija Univerzitetska knjiga, Ministarstvo obrazovanja, nauke, kulture i sporta, Sarajevo, 316 str.

22. Cvitković, Ivan (1995), Sociologija religije, Biblioteka Znanstvena misao, Bosna Public, Sarajevo, 330 str.

23. Cvitković, Ivan (1991), Krleža, Hrvati i Srbi, Biblioteka posebnih izdanja Oslobođenje public / Institut za proučavanje nacionalnih odnosa, Sarajevo, ISBN 86-319-024-3, 183 str.

24. Cvitković, Ivan (1990), Sociološke karakteristike religioznosti stanovništva BiH, (Manuskript), Naučnoistraživački projekt: Nacionalni i religijski odnosi u BiH, Institut za proučavanje nacionalnih odnosa, Sarajevo, Sveska br. 5, 290 str.

25. Cvitković, Ivan (1989), Savez komunista i religija, 3. dopunjeno izd., Politička biblioteka, Oslobođenje, Sarajevo, ISBN 86-319-0146-6, 247 str.

26. Cvitković, Ivan (1987), Sloboda religije u socijalističkom samoupravnom društvu, Marksistička i politička biblioteka, Edicija "Društvo i vreme" 10, Dnevnik, Novi Sad, 68 str.

27. Cvitković, Ivan (1986), Religija: pitanja i odgovori. Marginalije uz razgovor o temi "Mladi i religija”, 2. izd., Biblioteka Marksističke sveske, Centar društvenih aktivnosti RKSSO BiH, Sarajevo, 85 str.

28. Cvitković, Ivan (1986), Ko je bio Alojzije Stepinac, 2. izd., Politička biblioteka, Oslobođenje, Sarajevo, 333 str.

29. Cvitković, Ivan (1986), Ko je bio Alojzije Stepinac, Politička biblioteka, Oslobođenje, Sarajevo, 333 str.

30. Cvitković, Ivan (1985), Savez komunista i religija, 2. dopunjeno izd., Politička biblioteka, Oslobođenje, Sarajevo, 237 str.

31. Cvitković, Ivan (1983), Religija: pitanja i odgovori. Marginalije uz razgovor o temi "Mladi i religija", Biblioteka Marksističke sveske, Centar društvenih aktivnosti RKSSO BiH, Sarajevo, 85 str.

32. Cvitković, Ivan (1982), Savez komunista Jugoslavije i religija, Biblioteka "Politička škola”, Kolo 2, Radnička štampa, Beograd, 125 str.

33. Cvitković, Ivan (1981), Religije u Bosni i Hercegovini, Univerzal, Tuzla, 105 str.

34. Cvitković, Ivan (1980), Bilješke o religiji, Politička biblioteka, Oslobođenje, Sarajevo, 164 str.

35. Cvitković, Ivan (1980), Marksistička misao i religija (kritika teološke kritike odnosa marksizma i socijalizma prema religiji i religijskim zajednicama), Svjetlost, Sarajevo, 225 str.

36. Cvitković, Ivan (1974), Društvo - religija - mladi, Politička biblioteka, Centar za marksističko obrazovanje i izdavačku djelatnost Konferencije Saveza omladine Bosne i Hercegovine, Sarajevo, 180 str. 
ligijskoj zbilji bosanskohercegovačkoga društva. Njegove knjige ne pozivaju na oružanu nego na permanentnu intelektualnu revoluciju, na radikalnu promjenu odnosa prema glavnim protagonistima upropaštavanja suvremenoga bosanskohercegovačkog društva (političkim strankama i religijskim zajednicama). Osvrnut ću se na sljedeće knjige:

1. Sociologija religije

2. Sociologija obreda

3. Religija u raljama politike

4. Religija u zrcalu teorija

5. Moj susjed musliman

6. Ganga: pjesma o životu u Hercegovini (Sociologijske marginalije o gangi)

7. Ko je bio Alojzije Stepinac?

\section{Sociologija religije}

Knjiga Ivana Cvitkovića Sociologija religije predstavlja prvi sveobuhvatni sveučilišni udžbenik u Bosni i Hercegovini u kojem se religiji pristupa iz perspektive znanstvenika, a ne iz perspektive borbenoga vjernika ili borbenoga nevjernika, a to znači iz perspektive znanstvenika koji pristupa religiji kao društvenoj činjenici, kao ljudskome proizvodu nastalom temeljem njegova vjerovanja u Sveto. A to znači da Cvitkoviću, kao i drugim suvremenim sociolozima religije, nije bitno "je li istinito ono u što ljudi vjeruju”, nego im je jedino važno ono "što ljudi u toj religiji drže zbiljskim i što pretvaraju u svoja svakodnevna djelovanja” (Knoblauch 2004: 11).

Polazeći s tog stajališta, ne čudi da se profesor Cvitković upustio u "avanturu" pisanja ovoga udžbenika da ovdašnjoj sveučilišnoj, ali i svekolikoj “općoj” javnosti - zasićenoj besadržajnim ponavljajućim religijskim praksama ponudi uistinu jedno vrijedno djelo koje će im, slijedeći Weberovo shvaćanje značenja religijskih vjerovanja za svakodnevno djelovanje ljudi, omogućiti da shvate razloge, načine i smisao djelovanja kako kršćana, muslimana i Židova tako i Hindusa i budista itd. A da je Cvitkovićev udžbenik sociologije religije omogućio upravo to, potvrđuje i činjenica da je knjiga doživjela četiri izdanja $^{2}$ i da su neki njezini dijelovi iz prva dva izdanja proizišli u zasebne knjige kao npr. Religije suvremenoga svijeta te Rječnik religijskih pojmova.

\footnotetext{
${ }^{2}$ 1. Cvitković, Ivan (1995), Sociologija religije, Biblioteka Znanstvena misao, Bosna Public, Sarajevo, 330 str.; 2. Cvitković, Ivan (1996), Sociologija religije, Edicija Univerzitetska knjiga, Ministarstvo obrazovanja, nauke, kulture i sporta, Sarajevo, 316 str.; 3. Cvitković, Ivan (2004), Sociologija religije, 3. izd., DES, Sarajevo, 443 str.; 4. Cvitković, Ivan (2007), Sociologija religije, 4. izd., DES, Sarajevo, 443 str.
} 
U ovoj knjizi Cvitković nudi više socioreligijskih interpretacija religije, odnosno više različitih sociologijskih određenja pojma religije. Radi što potpunijeg obrazloženja što je to religija, on govori o kontroverzama o korijenima religije kao i o stavovima o religiji kao grupnome fenomenu. Uz to, poput mnogih svjetski poznatih sociologa religije, kao npr. Sabina Acquavive, Petera Bergera, Thomasa Luckmanna, Jose Casanove, Detlefa Pollacka i drugih, Cvitković daje poseban osvrt o Svetom u sekulariziranome svijetu, o povratku Svetog u vremenu za koje su se mnogi nadali da je u njemu religija završila svoje ovozemaljsko poslanje (i postojanje). Stoga je za Cvitkovića neizostavno bilo pozabaviti se u ovoj knjizi suvremenim problemima sociologije religije, njezinim predmetom i zadaćama, sociologijskim determinantama religioznosti, utjecajem religije u društvu te metodama sociologijskog istraživanja religije. Slijedeći temeljne ideal-tipske postavke Maxa Webera, Cvitković nam u ovoj knjizi radi boljeg razumijevanja određenih religijskih pojmova i fenomena predočuje osnovne tipologije u sociologiji religije, što se posebice odnosi na religije kao takve, zatim na religijske organizacije, njihove vođe, vjernike i njihove odnose s državama.

Pošto je religija društvena tvorba, nastala u određenome vremenu, na određenome prostoru, u određenoj kulturi i civilizaciji, ona je u bitnome jedna od važnih sastavnica suvremenih svjetskih kultura i civilizacija. Dovoljno je pogledati religijsku kartu svijeta da bismo se u to uvjerili. Temeljem te karte i temeljem analize oblika privređivanja u zemljama u kojima je neka religija većinska, moguće je odrediti i načine privređivanja u njima. Jer, oslanjajući se na knjigu Maxa Webera Gesammelte Aufsätze zur Religionssoziologie (Prilozi o sociologiji religije), odnosno na poglavlje u tome izdanju Die Wirtschaftsethik der Weltreligionen (Privredna etika svjetskih religija) (Weber 1989a), a potom i na djela Niklasa Luhmanna Die Religion der Gesellschaft (Religija društva) (Luhmann 2000) i Funktion der Religion (Funkcija religije) (Luhmann 1982), može se govoriti, a to prof. Cvitković upravo čini, o odnosu religije prema društvenim konfliktima, gospodarstvu, politici, demokraciji i ljudskim pravima, naciji, braku, ženi, globalizaciji, ekologiji. I naravno na poseban način o sekularizaciji, o-u sociologiji religije - prijepornoj točci o tome je li sekularizacija mit ili stvarnost. Cvitković ne izbjegava govoriti o marksističkoj teoriji religije, jer je ona u bitnome zrcalila odnose države i religijskih zajednica u socijalističkim zemljama istočne i jugoistočne Europe, zatim Kine i Kube, kao ni o ateizmu kao vječitom "pratitelju” religije. Naime, uvijek je uz vjernike bilo i nevjernika, uvjerenih ateista, ponekad i veoma borbenih protivnika religije, ljudi koji nisu vjerovali u nadnaravna bića, u bogove, božanstva. 
Cvitković u ovoj knjizi govori i o teorijskim kontroverzama o budućnosti religije te u tome smislu naznačuje tri do sada predložena, ali ne i općeprihvaćena modela: 1) Religija je prirođena čovjekova potreba i kao takva ima svoju "prošlost, sadašnjost i budućnost". Ona "ostaje vječita", odnosno vječno živa i neuništiva; 2) Jednu religiju zamijeniti drugom, što su (bezuspješno) pokušavali Auguste Comte nastojeći tradicionalnu religiju zamijeniti religijom čovječanstva (Comte 1852) i Ludwig Feuerbach koji je kršćansku religiju kao religiju patnje (Religion des Leidens) ${ }^{3}$ želio zamijeniti religijom ljubavi (Religion der Liebe); ${ }^{4}$ 3) Religija će nestati nestankom kapitalizma, napretkom (promjenom) kulture te napretkom znanosti.

\section{Socioligija obreda}

Druga važna knjiga Ivana Cvitkovića Sociologija obreda (2014) sadrži najvažnije religijske obrede kako one iz "velikih" i "malih" religijskih tradicija tako i one religijske obrede iz naših južnoslavenskih područja, temeljem čega mnogi od nas - koji to hoćemo - možemo reflektirati svoju vlastitu zavičajnu, kako religijsku tako i narodnosnu tradiciju. A to je Cvitković mogao postići jer je pri izradbi ove knjige sebi postavio sasvim jasan i određen cilj: "ne poučavati bilo koga u religijskim obredima, već pokušati - maksimalno poštujući znanstvenu objektivnost i neutralnost - čitateljima različitih svjetonazora, religijskih kultura i tradicija, predočiti znanja o sličnostima i razlikama u obredima, te njihovim sociologijskim značenjima", jer sociologiju i sociologe zanimaju "vanjske, vidljive ('opipljive') odlike vjerskih obreda" bez obzira na to u kojoj se religijskoj tradiciji oni prakticirali. Jer, kada bismo svoje vlastite religije "ogoljeli" od obreda, ne bismo ih više mogli prepoznati, one bi, kako to Cvitković navodi pozivajući se na G. Vernona, bile "mrtve".

I ne samo religije nego i mnogi segmenti iz našeg osobnog i društvenog života. Naime, obredi su usmjereni prema Nadnaravnome, prema Prirodi ili su pak vezani za važnije trenutke našega života. Uz to, oni mogu biti pojedinačni i skupni, kućni (domaći, profani) i svečani (“misni”, sakralni), mogu ih izvoditi obični ljudi (što je rijetkost) i za to osposobljeni i uz sve to religijski muzikalni pojedinci (M. Weber). Uz to, obrede je potrebno vršiti određenim "obrednim" jezikom (inače neće vrijediti), potrebno ih je čuvati i redovito održavati, a sve, kako navodi Cvitković, radi povezivanja vjerničke (druš-

\footnotetext{
3 "Die christliche Religion ist die Religion des Leidens" (Feuerbach 1903-1911).

4 "Du bist nur, wenn du liebst; Sein ist erst Sein, wenn es Sein der Liebe ist, aber zugleich geht in der Liebe dein persönliches Dasein, dein abgesondertes Fürdichsein zu Grunde. Du bist nur noch in dem geliebten Gegenstande, Alles außer ihm, du selbst ohne ihn bist dir Nichts. Die Liebe ist die Quelle aller Freuden, aber auch aller Schmerzen.” (Feuerbach 1830).
} 
tvene) zajednice. Njima se izražava ne samo društveni nego i zdravstveni status onih koji u njemu sudjeluju. Uz to, oni su vjerni pokazatelji čovjekovog religijskog, veoma često nacionalnog, političkog, ali i ideološkog identiteta.

Obredi su veoma različiti. Cvitković ih svrstava u nekoliko skupina: dobni, očišćujući, blagdanski, funkcionalni, zahvaljujući, gozbeni, kalendarski, ratni te obredi žrtvovanja. I time nas na znanstven i znalački stručan način upoznaje s religijskim i kvazireligijskim obredima nastalim u različitim religijskim tradicijama tijekom njihova trajanja. Zapravo, time nas upoznaje s odnosom čovjeka pojedinca prema Nadnaravnome, prema Svetom, prema Onome kome se on obraća za pomoć u različitim životnim prilikama, ali i kome se klanja i zahvaljuje za primljenu pomoć.

Jedan od recenzenata ove knjige, filozof, dr. sc. Željko Pavić iz Zagreba, istaknut će da je ovo prvi (pionirski) pothvat u našoj znanstvenoj sredini na temu sociologije koja je u tom disciplinarnom obliku ostala do danas potpuno nerazvijena. Naime, Pavić ističe kako se Cvitković u ovoj knjizi neprestano suočavao s dva velika problema: kao prvo, s nakanom da prikaže "strukturu i načine vršenja obreda u svim 'velikim' i 'malim' religijama”, i drugo, da ponudi objektivne kriterije "u pristupu svim tim najraznovrsnijim religijskim, vjeronazornim i teologijskim shvaćanjima obredā”. Kako bi u svojim razmatranjima izbjegao "kriterije vrijednosne prosudbe", a time i "opasnost potpunog ukidanja zahtijevane znanstvene objektivnosti”, Cvitković će se u takvoj teškoj situaciji opredijeliti “'za najsretniji, srednji put 'deskriptivnoga' pristupa: najprije će analizirati i opisati obrede i njihovo vršenje u svim velikim i malim religijama, bez donošenja vrijednosnoga suda, kako bi se - u drugom koraku - putem njihove usporedne analize sâm čitatelj pokušao navesti na razmišljanje o njihovom mogućem vrednovanju za samu njegovu religijsku zbiljnost”.

\section{Religija u raljama politike}

Treća knjiga Ivana Cvitkovića na koju bih se želio osvrnuti ima naslov Religija u raljama politike (2019). Ta je knjiga posebna znanstveno-stručna poslastica ne samo za socioreligijske nego i za druge ovozemaljske "duhovne sladokusce". Ona je dakle iznenadna intelektualna poslastica koja će im pomoći da konačno "otvore oči” i na zoran način (u)vide u kojoj se i kakvoj međusobnoj povezanosti nalaze religija i politika, odnosno religijske zajednice i država. Zapravo, nijedno drugo djelo iz područja sociologije religije, ne samo u Bosni i Hercegovini nego ni u njezinu okruženju, ne govori na tako iscrpan i znanstveno utemeljen način o odnosu religije i politike, Crkve i dr- 
žave, religije i demokracije, religije i (političkih) izbora, religije i siromaštva, religije i nasilja kao ova Cvitkovićeva knjiga. Rijetke su knjige koje se kao ova bave kontroverzama oko svetogrđa, opsjednutošću vjerskih službenika komunizmom (posebno u postsocijalističkim zemljama), doprinosom Crkve razvoju ateizma, utjecajem migracija na promjenu religijske karte Europe i, u tome smislu, odnosom religije i Europske unije.

Kad je riječ o odnosu religije i politike Cvitković naznačuje tri modela tih odnosa: 1) Religijsko-politička sinteza; 2) Religija iznad politike (npr. hinduizam) i 3) Religija i politička moć kao zasebne društvene činjenice. Polazeći sa stajališta da odnos religije i politike nije isto što i odnos Crkve i države, on ističe da je to zbog toga što se odnos "religija - politika" tiče svih građana jedne države (barem onih koji se izjašnjavaju kao vjernici), dok se u drugome slučaju kod odnosa "Crkva - država" radi o odnosu dviju institucija. Međutim, kad je riječ o odnosu religije $i$ demokracije, Cvitković će posebnu pozornost posvetiti pojmu demokracije i objasniti odnose kršćanstva (posebno protestantizma) i demokracije te islama i demokracije.

Posebnu pozornost Cvitković posvećuje odnosu religije i siromaštva, što se dodatno može vidjeti i u njegovoj knjizi Socijalna učenja u religijama (2007). Kako nikada nije suvišno govoriti o društvenim uzrocima, ali i posljedicama siromaštva, Cvitković iznova upozorava da je siromaštvo postalo svjetski problem, što znači da živimo u vremenu u kojemu bogatiji postaju još bogatijim, a siromašni još siromašnijim.

Uz to, Cvitković ukazuje na činjenicu da nasilje spada u one teme o kojima se najmanje piše, ali i u teme koje su najviše prisutne u društvenim odnosima, posebno kad je riječ o nasilju uime religija, a toga je, kako on kaže, svakim danom sve više, za što navodi i jako puno primjera. Uz napomenu da on ovdje ukazuje na činjenicu da se ne smije zaboraviti ni nasilje unutar samih religija i religijskih zajednica.

Rijetko ćemo naći nekoga teologa kao možebitnoga poznavatelja sadržaja određene (njegove) religije da će govoriti o humoru, o smijehu kao nečemu pozitivnome u religiji. Jer svete knjige nigdje ne navode da se Jahve, Bog, ili pak Allah nekada u nekoj prigodi možda i nasmijao. Uvijek je riječ o Božjoj srdžbi, prijetnji, odmazdi i osveti. ${ }^{5}$ Stoga i Cvitković s pravom u poglavlju Politika ismijavanja religije govori, između ostalog, o odnosu humora i religija, o postojanju humora u religijama i o predrasudama kao glavnim izvorima ismijavanja religija. On ne bježi govoriti o posebnom obliku humora, o vicevima u čijem središtu su svećenici, sveštenici i imami. Kao izvrsnog

\footnotetext{
${ }^{5} \mathrm{O}$ toj vrsti smijeha pisao sam u tekstu "Rideo ergo sum" - Smijem se, dakle postojim, u: http://www.prometej.ba/clanak/kultura/rideo-ergo-sum-smijem-se-dakle-postojim-1935.
} 
promatrača društvenih zbivanja njega interesiraju i kontroverze oko svetogrđa pri čemu polazi od postavke da je svetogrđe sadržano u zakonodavstvu i u zakonodavnoj praksi. U tu svrhu osvrće se na Zakon o slobodi vjera i pravnom položaju crkava i vjerskih zajednica u Bosni i Hercegovini, koji je Međureligijsko vijeće pripremilo, a Parlament Bosne i Hercegovine usvojio još davne 2004. godine, te navodi da se u čl. 5, stav 2 zabranjuje javna upotreba "službenih simbola, znamenja ... crkve ili vjerske zajednice bez suglasnosti nadležnih vlasti crkve ili vjerske zajednice". Osim toga, važno je i određivanje granice između slobode izražavanja i svetogrđa.

Kada danas slušamo predstavnike vjerskih zajednica, primijetit ćemo njihovu "opsjednutost" govorom o komunizmu, i to stoga što je antikomunizam u tradiciji svih naših religijskih zajednica, uz napomenu da su devedesete godine prošloga stoljeća temeljno promijenile bosanskohercegovačko društvo. Prema onome što se predočuje u iskazima pripadnika tih vjerskih zajednica, stječe se dojam da su u Bosni i Hercegovini, ali i u drugim postsocijalističkim zemljama, za sve što je loše u današnjemu društvu krivi komunisti i socijalizam. Da bi se barem donekle stvari razjasnile, Cvitković razmatra odnose religija-politika u postjugoslavenskim zemljama u kojima su vladali socijalistički režimi te se bavi razlikama između staljinizma i nacizma, govoreći istodobno i o političkim religijama u što su se bili pretvorili fašizam, nacionalsocijalizam i boljševizam. U poglavlju pod veoma intrigantnim naslovom Doprinos Crkve razvoju ateizma / Mjesto ateizma u politici i praksi postsocijalističkih društava Cvitković ponajprije definira pojmove ateizma i agnosticizma navodeći uzroke njihova nastanka, da bi potom govorio o ateistima - razočaranim vjernicima, zatim o ateizmu kao intelektualnome negiranju Boga, kao i o ideološkom, etičkom, socijalnom, prividnom, prikrivenom, metodološkom te "religijskom" ateizmu.

Kao sociologa, Cvitkovića interesiraju suvremene migracije, njihovi uzroci, kao i njihov utjecaj na promjenu religijske karte Europe. U tome smislu govor o suvremenim migracijama istodobno je govor o političko-ekonomskim problemima u zemljama iz kojih dolaze "izgubljeni ljudi", kao i političko-ekonomskim problemima u zemljama u koje su došli, te ističe bojazan koju domicilno stanovništvo ima prema doseljenicima (migrantima). Najnovija zbivanja s migrantima koji su se na svome putu za najrazvijenije europske zemlje kao što je npr. Njemačka zatekli u Bosni i Hercegovini, pokazuju obostrane bojazni: kako migranata prema domicilnome stanovništvu tako i domicilnoga stanovništva prema njima te pri tome ukazuje na važnost koju religijske institucije imaju kako za domicilno stanovništvo tako, ponajviše, za 
doseljenike (okupljanje oko hramova u središtima, ali i na periferiji urbanih sredina).

Uz to, Cvitković govori o značenju odnosa religije i Europske unije osvrćući se pri tome kako na doprinos Europe i Europske unije razvoju religijskih sloboda tako i na izazove europskom jedinstvu koji postaju prijetnja i njenom nestanku. Istodobno se bavi odnosom nacionalnog i europskog, europskim identitetom, kao i odnosom Europske unije i pravoslavlja te islama.

\section{Moj susjed musliman}

Posebnu pozornost zaslužuje Cvitkovićeva knjiga Moj susjed musliman (2011). Riječ je o knjizi čovjeka odraslog u hrvatskoj, katoličkoj obitelji i njegovu viđenju života velikoga broja Hrvata katolika s većinskim stanovništvom u Bosni Hercegovini, s Bošnjacima koji su najvećim dijelom muslimani. Knjiga se pojavila 2011. godine, u vrijeme nakon rušenja njujorških tornjeva, u vrijeme zapjenjenih i bučnih, nestručnih i opakih rasprava o muslimanima i islamu općenito, u vrijeme zapjenjenih rasprava o vehabizmu i selefizmu, o mudžahedinima i islamskim fundamentalistima, kao i o mnogim drugim podruštvovljenim pojavnim oblicima islama, od nošenja rupca (marame) do praktične provedbe šerijatskoga zakona.

Gledajući iz današnje perspektive, nije u to vrijeme bilo lako pisati ovu knjigu. Razlozi nisu trebali biti napisani, osjećali su se "u zraku": muslimane na europskim, ali i na ovim našim prostorima, doživljavalo se i još uvijek se doživljava kroz predrasude kao potencijalne neprijatelje, teroriste, ubojice, silovatelje, nasilnike i provalnike. I to samo stoga što ispovijedaju istu vjeru kao i oni koji danas islamsku vjeru zlo(po)rabe u političke svrhe, odnosno kao oni koji su stoljećima kao okupatori vladali ovim prostorima - s Osmanlijama. Polazeći s tih pozicija, novopridolazeći muslimani u Europu ne bi bili interesantni ni nama u Hrvatskoj ni u Bosni i Hercegovini ni ostalim neislamskim žiteljima Europske unije da s njihovim dolaskom nije došlo do kidanja i mrvljenja dosadašnjeg europskog religijskog krajobraza kojeg se smatralo područjem utemeljenim na kršćanskim vrijednostima i koje bi kao takvo trebalo i ostati. Iako to mnogi ne žele prihvatiti kao činjenicu, mora se poći od toga da su ti procesi mrvljenja i usitnjavanja geografskoga religijskog krajolika nezaustavljivi, kao i procesi protoka ideja i ljudi. Oni prerastaju u procese permanentnog mijenjanja religijske geografije, ne samo u zapadnoeuropskome području nego i u Bosni i Hercegovini, ali i u samoj Hrvatskoj.

Unatoč svemu, Cvitković će se - ne obazirući se na zapjenjene zagovornike mržnje prema muslimanima, na sve izraženiju islamofobiju u europskim 
društvima - usuditi ponuditi europskim, a time i hrvatskim kršćanima jedno uistinu izvanredno "nemuslimansko" objašnjenje tko su zapravo muslimani, u što (ili u koga) oni vjeruju, kojim se obredima služe te odakle muslimani u Bosni i Hercegovini, u Hrvatskoj, u Europi, kad su i odakle su došli?

Kao što muslimani znaju da su kršćani druge i drukčije vjere i identiteta negoli su to oni, tako i kršćani znaju da muslimanska vjera nije ista "k'o naša”, da im, dakle, religija, religijski obredi i religijski identiteti nisu isti, unatoč zajedničkom praocu Abrahamu. No, ni jednima ni drugima nije to bila smetnja da se na istome teritoriju formiraju i da već stoljećima usporedo žive dva razdvojena, zasebna i nespojiva načina života - kršćanski i islamski. A te zasebne, razdvojene i u religijskome smislu nespojive načine života omogućila je - unatoč činjenici da potječu iz istoga religijskog "gnijezda", iz istoga "krila Abrahamova" - religijski formirana kultura i u toj kulturi religijski formiran odnos pojedinca i "njegove" religijske zajednice prema ovozemaljskome životu, kao i prema nadnaravnome biću.

Cvitković je ovom knjigom želio upoznati Europljane, kako kršćane tako i ateiste i agnostike, dakle sve one kojima je nepoznata vjera muslimana i njihova religijska kultura, kao i "statističke" muslimane (dakle one koji su rođeni u sekularnim obiteljima koje potječu iz muslimanskoga kulturnog kruga), što je to islam kao vjera, kao kultura, kao civilizacija, kako bi mogli prihvatiti muslimana kao susjeda, kao prijatelja, poznanika, pa čak i kao neprijatelja (jer neprijatelja je potrebno poznavati kao i prijatelja da bi se znao odnositi prema njemu).

U knjizi Cvitković daje analizu stanja među muslimanima općenito, kao i analizu političkih kretanja među muslimanima, te iznosi sličnosti i razlike u vjerovanjima kršćana i muslimana uz navođenje moralnih vrednota, pouka i poruka obiju religija. Upravo zbog važnosti tih odnosa Cvitković se na poseban način bavi ne samo odnosom kršćana na Zapadu prema islamu i muslimanima nego i odnosom muslimana prema Zapadu, kršćanstvu i kršćanima.

Posebnu pozornost Cvitković pridaje islamu i kršćanstvu u kontekstu demokracije i vjerskih sloboda te u tom smislu govori o u današnje vrijeme veoma važnoj temi, o muslimanima u Europi i Europskoj Uniji, o "europskome islamu", odnosno o islamu u Europi. Sve to naravno ne prolazi bez govora kako o kršćansko-muslimanskim konfliktima i nesporazumima i njihovome međusobnom nerazumijevanju tako i o kontroverzama oko pojmova "džihad", marama (rubac) i pravu na njezino nošenje u javnome prostoru, o društvenome statusu muslimanki unutar europskoga, a time i hrvatskoga društva.

Iako prof. Cvitković o vehabizmu i vehabijama, kao i kontroverzama koje su neodvojive od ovoga pokreta unutar islama kao religije, govori tek pri kra- 
ju knjige, to ni u kojem slučaju ne znači da tim temama i pojavnim oblicima islama i nama neobičnog i stranog tumačenja islama ne pridaje posebnu važnost. Stoga on i želi kazati da je religija u terorizmu oteta.

\section{Religija u zrcalu teorija}

Da bi se moglo govoriti o teorijskim pristupima religiji, potrebno je pročitati Cvitkovićevu knjigu Religija u zrcalu teorija (2016). Ta knjiga će mnogima koji se žele baviti odnosima religije i društva te značenjem i ulogom religije u suvremenome, ali i u ranijim društvima pomoći kako ispravno odrediti taj odnos, kako mu pristupiti i kako ga interpretirati. Cvitković s pravom smatra da je te međusobne odnose religije i društva potrebno uvijek kontekstualizirati, staviti u kontekst vremena, u kontekst određenog podneblja i širih društvenih i političkih odnosa. U tu svrhu, potrebno je najprije objasniti temeljne pojmove: što je to religija, vjera, koja je to uloga i koje je to značenje religije u društvu te koju funkciju religija ispunjava na individualnoj, ali i na široj društvenoj razini. Cvitković smatra da je ono što obilježava suvremenu socioreligijsku zbilju zapravo jedan paradoks: s jedne strane imamo snažne procese sekularizacije uz istodobno postojanje tradicionalne religioznosti, religijskih sloboda, tradicionalne (pučke) religioznosti, a na drugoj strani oživljavanje duhovnosti, pojavu fundamentalizama, religijskih nacionalizama te alternativnih religioznosti. Ne čudi stoga da su se upravo zbog takvoga stanja stvari rasprave o religiji, religioznosti, o religijskoj duhovnosti pojavile kako u tradicionalnim europskim i američkim zemljama tako i u postsocijalističkim zemljama. U nemogućnosti pronalaska jedne i jedinstvene općevažeće $i$ svevremenske definicije religije Cvitković (2016: 8) će reći: "nema univerzalne definicije religije koja bi važila za sve religije, i za 'sva vremena".

Iako je knjiga namijenjena sociološkim znalcima, kao dobar i predan učitelj Cvitković će smatrati potrebnim kazati da je posebno važno razlikovati religiju od vjere. Ta dva pojma nisu istoznačna. Vjera je čovjekov osobni odnos s Nadnaravnim (svejedno kako ga mi imenovali: Bog, Alah, Jahve, bog, duh), dok je religija ljudska tvorba. Ona nam pokazuje na koji način u nekoj određenoj kulturi pojedinac na vanjski način predočuje svoj odnos prema nadnaravnome biću. Stoga Cvitković s pravom postavlja pitanje nije li najveća izdaja vjere nastala njezinim pretvaranjem u religiju?

Cvitković ovdje obrađuje kako funkcionalističke i neofunkcionalističke teorije i stavove prema religiji njezinih predstavnika, tako i marksističke i neomarksističke teorije i stavove. Posebnu pažnju posvećuje odnosu prema vjeri, religijama i religioznosti postmodernističkih, sekularizacijskih, femini- 
stičkih te, svakako, globalizacijskih socioloških teorija, zatim odnosu prema religijama ekoloških i fundamentalističkih teorija, humanizmu, identitetu te pravnim teorijama. Ne zaboravlja obraditi i tzv. "ostale teorije", među koje on ubraja: altruističku, antropološku, kreacionističku, konstruktivističku, teoriju racionalnog izbora, zatim strukturalističke teorije.

\section{Ganga: pjesma o životu u Hercegovini (Sociologijske marginalije o gangi)}

Među Cvitkovićeva relevantna sociološka djela spada i knjiga Ganga: pjesma o životu u Hercegovini (Sociologijske marginalije o gangi) (2017). Kako sam navodi, pisanje ove knjige nije mu bilo ni "izraz čežnje za 'starim dobrim vremenima' (koja nisu bila nimalo dobra, jer su u njima prevladavali siromaštvo, bijeda, civilizacijska zaostalost) niti želja povezivanja prošlosti sa sadašnjošću (još manje s budućnošću), niti povezivanje 'starog' s 'novim",, nego mu je jednostavno bila želja da ovom knjigom o gangi otrgne od zaborava jedno vrijeme i jedan način života u Hercegovini koji gotovo više ne postoje, čime je, kako sam kaže, postao na neki način "arhivar hercegovačke prošlosti”. Osim toga, on u ovoj knjizi navodi osnovne podatke o Hercegovini, odnosno o Zapadnoj Hercegovini, te objašnjava što su za to zapadnohercegovačko područje značili i znače kamen, siromaštvo, stočarstvo, čatrnja, natalitet, jezik, migracije te objašnjava što je ganga, odakle je i od kada je u Hercegovini te navodi da ga u sociologijskome pogledu ganga zanima "jer je ta tema sociologijski neistražena, a i zbog zanemarenosti ove tematike u drugoj polovini XX. stoljeća". Jednostavno, ovo je osvrt na dio prošlosti u životu stanovništva Hercegovine. Rijetki su još oni koji su zainteresirani za pjesme gange, a posebice za pjevanje gange. Mlađim generacijama u Hercegovini ganga je dio folklora, odraz zaostalosti sredine iz koje i sami potječu.

Međutim, ovo djelo otkida od zaborava pjesmom iskazani način življenja u jednoj sredini (u zapadnoj Hercegovini) koju život - ni svakodnevni prirodni, a ni onaj društveni i politički (svejedno o kojem se tipu političkoga režima radilo) - nije nikada "mazio". Zbog prirodnog instinkta za održanjem, za jednostavnim egzistencijalnim preživljavanjem i opstankom na škrtoj kamenitoj zemlji, ljudi u Hercegovini su se koristili raznim oblicima stjecanja životnih dobara. Da bi iskazali vrijednost kako tih sredstava za preživljavanje tako i vrijednosti svakodnevnoga života, ljubavi i čežnje za vlastitim domom i obitelji, stvarali su i pjevali pjesmu - gangu. Ona je zrcalila život hercegovačkoga krša. Zbog nedostatka relevantnih socioloških empirijskih istraživanja, ove pjesme, skupljene na jednome mjestu, uz znalačka Cvitkovićeva 
objašnjenja konteksta u kojem su nastajale i u kojem su ih ljudi ovoga kraja pjevali, ovo će djelo biti od velike važnosti za stjecanje vjerne slike o životu u jednome kraju u jednome ne tako kratkome vremenu.

\section{Ko je bio Alojzije Stepinac?}

I na kraju, knjiga Ivana Cvitkovića Ko je bio Alojzije Stepinac? (1986) sve do danas ostat će djelo koje će samo rijetki htjeti spomenuti i citirati. Razlozi su bizarni, a najviše potječu iz krugova bliskih hijerarhiji Katoličke crkve u Hrvatskoj i Bosni i Hercegovini. Naime, oni se ne mogu pomiriti s činjenicom da se ipak našao netko izvan katoličkih teoloških krugova tko se usudio prozboriti o Stepincu na znanstven i na povijesnim dokumentima utemeljen način. Sve do danas ta je Cvitkovićeva knjiga ostala nešto najbolje napisano o kardinalu Alojziju Stepincu. To mi je osobno početkom 1980-ih potvrdio ramski fratar, fra Franjo Žilić, u našim čestim i sadržajnim razgovorima vođenim u ramskome samostanu u Šćitu. Naime, Cvitković u ovoj knjizi nije išao analizirati povijesne dokumente da bi optužio Alojzija Stepinca za suradnju s ustaškim režimom niti za stradanja Židova, Roma, Srba i drugih neistomišljenika režima, niti ga išao hvaliti da bi ga se beatificiralo i potom kanoniziralo. Sve što je Cvitković uradio bilo je traženje odgovora na pitanje tko je uistinu bio Alojzije Stepinac. Unatoč svim dokumentima koji su mu stajali na raspolaganju, Cvitković nije uspio (pro)naći pravi odgovor, zbog čega je i naslov knjige osvanuo s upitnikom Ko je bio Alojzije Stepinac? A da je to upravo tako potvrđuje i jedan od najrigidnijih katoličkih novinara, inače član Uređivačkoga kolegija Glasa Koncila, Tomislav Vuković, koji u svome tekstu "Stvaranje 'zločinca", objavljenom 10. veljače 2018. na stranicama sarajevskoga mjesečnika Svjetlo riječi, a ne u nekome katoličkome glasilu u Hrvatskoj, kaže sljedeće: "Među silnim mnoštvom knjiga o bl. Alojziju Stepincu, objavljenih nakon završetka Drugoga svjetskog rata pa sve do današnjih dana, vrijedi tek spomenuti dr. Ivana Cvitkovića, nekadašnjega istaknutog marksističkog mislioca, sociologa religije i sveučilišnoga profesora, i njegovo djelo Ko je bio Alojzije Stepinac? (NIŠRO Oslobođenje, Sarajevo, 1986). Ta knjiga, na 336 stranica po sebi ne zaslužuje neku pozornost, posebice s današnjega motrišta, zbog objave njemu potpuno nepoznatih dokumenata i činjenica vezanih uz zagrebačkoga nadbiskupa, koji su mu mogli pomoći u što objektivnijem sagledavanju teme kojom se bavi. Naime, u Cvitkovićevoj se knjizi s neznatnim i beznačajnim dopunama uglavnom recikliraju teze iznesene u knjizi Milana Stanića Suđenje Lisaku, Stepincu, Šaliću i drugim ustaško-križarskim zločincima i njihovim pomagačima (Zagreb, 1946.) i Jakova Blaževića Mač, 
a ne mir (Zagreb, Beograd, Sarajevo, 1980.). No, njezin naslov/upitnik - tko je bio Alojzije Stepinac? itekako odražava dvojbe, nedoumice i zbunjenost određenoga dijela, ne samo hrvatske, bosanskohercegovačke ili srbijanske nego i svjetske javnosti." Svoj tekst Vuković završava riječima: “Zaključno, Cvitkovićevo pitanje spomenuto na početku teksta - tko je bio Alojzije Stepinac - još će dugo odzvanjati u glavama mnogih!" (Vuković 2018).

Međutim, priča ne staje tu. Dok sam radio u Leksikografskome zavodu Miroslav Krleža u Zagrebu (1993-2005), radio se drugi svezak Hrvatske enciklopedije. Neki od članova uredništva, dr. sc. Slaven Ravlić, smatrali su potrebnim objaviti u 2. svesku Hrvatske enciklopedije i natuknicu o Ivanu Cvitkoviću, sociologu religije iz Bosne i Hercegovine. Za pisanje natuknice angažirao je i mene. Stupili smo u kontakt s prof. Cvitkovićem i - kao što je to uobičajeno - zatražili da nam pošalje najvažnije podatke o sebi i svome društvenom, političkom, znanstvenom i nastavnom djelovanju. On je to učinio. Mi smo temeljem toga, ali i temeljem drugih izvora, napisali natuknicu. Međutim, jedan od urednika u tome svesku, dr. sc. Trpimir Macan, nazvao me telefonom i pitao zašto smatram da u Hrvatskoj enciklopediji treba objaviti natuknicu o Ivanu Cvitkoviću. Naveo sam mu da je to potrebno učiniti temeljem činjenice da je Ivan Cvitković Hrvat, da je znanstvenik i sveučilišni profesor i da je objavio preko deset knjiga. Macan mi je potom rekao da ga neće uvrstiti jer je napisao knjigu o Alojziju Stepincu. Rekao sam mu da to ne može biti razlog za neuvršćivanje Cvitkovića u Hrvatsku enciklopediju. Ponovno sam mu naveo da su mi istaknuti bosanski fratri izravno potvrdili da je to do tada najvjerodostojnije djelo o Alojziju Stepincu. Uostalom, rekao sam mu, ako u Hrvatskoj enciklopediji može biti objavljena natuknica o Jakovu Blaževiću koji je pisao optužnicu protiv Stepinca, zašto ne može biti objavljena natuknica o čovjeku koji je to na vjerodostojan način evidentirao. Nažalost, sve je bilo uzalud. Tek kasnije, kad je dr. sc. Slaven Ravlić postao glavni urednik Hrvatske enciklopedije i kada je Hrvatska enciklopedija dobila svoju online-verziju, pojavila se u njoj i natuknica o Ivanu Cvitkoviću kao bosanskohercegovačkome, ali ne i kao o hrvatskome sociologu, ${ }^{6}$ na što

\footnotetext{
${ }^{6}$ Cvitković, Ivan, bosanskohercegovački sociolog (Mostar, 5. V. 1945.). Diplomirao sociologiju na Fakultetu političkih nauka u Sarajevu 1967., doktorirao na Fakultetu za sociologiju, novinarstvo i političke znanosti u Ljubljani 1978. Redoviti profesor na Fakultetu političkih nauka u Sarajevu (od 1989.). Od 2008. dopisni, a od 2012. redoviti član Akademije nauka i umjetnosti $\mathrm{BiH}$. Osnovno je područje njegova znanstvenog i nastavnog rada sociologija religije. Djela: Rječnik religijskih pojmova (1991), Sociologija religije (1995), Religije suvremenoga svijeta (1999), Konfesija u ratu (2004), Hrvatski identitet u BiH (2005), Sociološki pogledi na naciju i religiju (2005), Socijalna naučavanja u religijama (2007), Moj susjed musliman (2011) i dr. (u: http://www.enciklopedija.hr/Natuknica.aspx?ID=69434\#Bottom)
} 
sam ponovno reagirao u listopadu 2013. u pisanome obliku. ${ }^{7}$ Nažalost u tome dijelu moje reakcije, sve je ostalo nepromijenjeno.

$* * *$

Zaključno se može reći sljedeće: kao i drugi sociolozi, i Ivan Cvitković slijedi i ispunjava temeljnu zadaću sociologije: opisati i objasniti društvene promjene koje se, kolikogod to na prvi pogled izgledalo tako, nikada ne pojavljuju slučajno i izvan društvenih struktura. Temeljitijim znanstvenim promatranjem uviđaju se određene strukture i određeni modeli koji se "neovisno o pojedincima i konkretnim povijesnim društvima uvijek iznova manifestiraju" (Treibel 2008: 11). A to znači da Cvitković spada u skupinu sociologa koje ne interesira samo puko opisivanje onoga što se dogodilo, nego on uvijek minuciozno traga za uzrocima, za razlozima koji su doveli do neke određene društvene mijene ili do određene društvene pojave, kako u predratnome tako i ratnom te posebno u poslijeratnome razdoblju.

\footnotetext{
${ }^{7}$ Poštovane/Poštovani, očekivao sam da će članci/natuknice barem u Hrvatskoj enciklopediji biti napisani/ne "kako Bog zapovijeda". Nažalost, nije tako. Evo primjera u biografiji: CVITKOVIĆ, Ivan. Pridjev "bosanskohercegovački” piše se zajedno, a ne razdvojeno kao kod Vas (bosansko hercegovački). Razlog: odnosi se na državu Bosnu i Hercegovinu kao jednu cjelinu. A da se odnosi na jednakovrijedne dijelove: na Bosnu i Hercegovinu, ni tada se ne bi pisalo kako Vi pišete, nego s crticom: bosansko-hercegovački (Vidjeti Rječnik hrvatskoga jezika, LZMK, ur. J. Šonje).

Drugo, prof. Cvitković nije diplomirao niti predaje na Fakultetu političkih znanosti u Sarajevu, nego na Fakultetu političkih nauka u Sarajevu. Također, on nije dopisni član Akademije znanosti i umjetnosti $\mathrm{BiH}$, nego redoviti član Akademije nauka i umjetnosti Bosne i Hercegovine (vidjeti: http://www.anubih.ba/index.php?option $=$ com_content\&view $=$ article\&id $=5$ $9 \&$ Itemid $=100 \&$ lang $=h r$ ). Valjda ime institucije ne bi trebalo prevoditi. Kako bi bilo da netko u BiH prevodi HAZU u HANU.

I ono što je najvažnije: mislim da akademik Cvitković zaslužuje malo opsežniju enciklopedijsku natuknicu barem u (virtualnoj) Hrvatskoj enciklopediji. Ovim bi trebalo ispraviti nepravdu koja mu je nanesena u ranijem periodu kada neki "izvorni” Hrvati nisu dozvolili da se njegova biobibliografija nađe u tiskanome izdanju Hrvatske enciklopedije. Evo linka za biografiju: http://www.anubih.ba/index.php?option=com_content\&view=article\&id=243\%3 Aivan-cvitkovi\&catid=27\&Itemid=100\&lang $=\mathrm{hr}$

Dalje, po čemu su npr. Ivan Lovrenović i Željko Ivanković hrvatski (književnici...), ili Mile Babić hrvatski (teolog), a Ivan Cvitković bosanskohercegovački (sociolog). Je li to po mjestu rođenja, življenja ili opet - ne daj, Bože - po nekome drugom načelu? Znači, ne može se u BiH biti hrvatski sociolog, ali može hrvatski književnik i hrvatski teolog, hrvatski vjerski pisac, itd. Malo čudna logika, zar ne?

Sitnice - koje život znače.

Srdačan noćobdijski pozdrav.

Ivan Markešić
} 
Cvitkovićev hod kao sudionika u društvenim zbivanjima novovjeke predratne, ratne i poslijeratne Bosne i Hercegovine i kao neumornog istraživača uzroka i posljedica tih zbivanja sa socioreligijskoga stajališta započinje davne 1969. godine tekstom "Političke marginalije na temu: Omladina i religija", objavljenom u sarajevskom časopisu Lica. Bit će to početak jedne uistinu plodne znanstvene i stručne socioreligijske karijere usredotočene na istraživanje odnosa religije i društva, religije i politike, crkve i politike, religije i nacije, religije i rata i drugih socioreligijskih odnosa. Bit će to početak kojemu se još uvijek ne nazire kraj. A tako je moglo biti zahvaljujući također gospođi Milici, Ivanovoj supruzi, koja je mnogo toga osobnog žrtvovala i ugradila u ono što je on postigao. Bila je to jedna lijepa sinergija bračnih partnera koju se u ostvarivanju osobnih karijera rijetko susreće. Stoga je ovaj njegov uspjeh ujedno i njezin, na čemu im oboma čestitam, od srca.

Kao što iz gornjega teksta proizlazi, Cvitkovićeva djela bjelodano svjedoče erudiciju, jedno uistinu zavidno obrazovanje i izvrsno poznavanje velikih svjetskih religijskih sustava koje nije nastalo slučajno, već upornim samoprijegornim radom, ona svjedoče o njegovom - unatoč postojanju partijskih stega - hrabrom upuštanju u istraživanje najvažnijih odnosa u jednome društvu - odnosa religije i društva, crkve i politike. Iako bi mnogi, s današnje točke gledanja, mogli reći da to istraživanje nije bilo s distance, već s pozicije moći u odnosu na nemoć i društvenu marginaliziranost religije i religijskih zajednica, moram ipak reći da to nije istina. Cvitkovićevi tekstovi bili su u to vrijeme prijeko potrebni, oni su relaksirali ondašnju društvenu i političku zbilju, oni su pobijali uvriježeno shvaćanje nekih autora da će religija iščeznuti, odnosno da je više nema, i pokazivali da su religija i religijske zajednice tu, da su svakim danom sve življe i društveno utjecajnije i da im se mora posvetiti dužna pažnja. A to je moglo tako biti jer se Cvitkovićevo bavljenje religijom i religijskim zajednicama odvijalo u razdoblju međusobnoga razumijevanja socijalističkoga sustava i religijskih zajednica, u razdoblju koje počinje sredinom sedamdesetih i traje do kraja osamdesetih godina 20. stoljeća, u razdoblju u kojem dolazi do uspona i uspostave boljih državno-crkvenih odnosa, u razdoblju u kojemu se u srednjeeuropskim, istočnoeuropskim i jugoistočnoeuropskim zemljama počinju odvijati naočigled suprotstavljeni procesi. S jedne strane, nastavlja se već započeti trend opadanja crkvenosti, dakle sve veći broj ljudi prestaju biti članovi crkava i vjerskih zajednica, dok, s druge strane, počinje oživljavati vjerski život, kako na individualnoj, tako i na institucionalnoj razini, što su pokazivala i sociološka i crkvena istraživanja u tome razdoblju (Pollack 1998: 13). 


\section{Literatura}

Comte, Auguste (1852), Catéchisme positiviste ou sommaire exposition de la religion universelle, Pariz.

Cvitković, Ivan (1986), Ko je bio A. Stepinac? Oslobođenje, Sarajevo.

Cvitković, Ivan (1995), Sociologija religije, 1. izd., Bosna Public, Sarajevo.

Cvitković, Ivan (1996), Sociologija religije, 2. izd., Ministarstvo obrazovanja, nauke, kulture i sporta, Sarajevo.

Cvitković, Ivan (2004), Sociologija religije, 3. izd., DES, Sarajevo.

Cvitković, Ivan (2007), Sociologija religije, 4. izd., DES, Sarajevo.

Cvitković, Ivan (2011), Moj susjed musliman, Školska knjiga, Zagreb.

Cvitković, Ivan (2014), Sociologija obreda, 1. izd., Nacionalna i univerzitetska biblioteka Bosne i Hercegovine, Sarajevo.

Cvitković, Ivan (2016), Religija u zrcalu teorija, Centar za empirijsko istraživanje religije, Sarajevo.

Cvitković, Ivan (2017), Ganga: pjesma o životu u Hercegovini (Sociologijske marginalije o gangi), University Press / Plejada, Sarajevo / Zagreb.

Cvitković, Ivan (2019), Religija u raljama politike, Akademija nauka i umjetnosti Bosne i Hercegovine, Sarajevo.

Elias, Norbert (2005), Studien über die Deutschen. Machtkämpfe und Habitusentwicklung im 19. und 20. Jahrhundert, Gesammelte Schriften in 19 Bänden, Band 11, Herausgegeben von Michael Schröter, Bearbeitet von Nico Wilterdink, Suhrkamp, Frankfurt/M. 2005.

Elias, Norbert (2003) Engagement und Distanzierung: Arbeiten zur Wissenssoziologie I, Gesammelte Schriften in 19 Bänden, Band 8, Suhrkamp, Frankfurt am Main.

Feuerbach, Ludwig (1830), Gedanken über Tod und Unsterblichkeit, Stein, 1830.

Feuerbach, Ludwig (1903-1911), Sämtliche Werke, hrsg. von W. Bolin und F. Jodl, Stuttgart, Frommann, 10 Bände.

Hrvatska enciklopedija, odrednica Cvitković, Ivan, Leksikografski zavod Miroslav Krleža. Dostupno na: http://www.enciklopedija.hr/Natuknica.aspx?ID=69434\#Bottom.

Knoblauch, Hubert (2004), Sociologija religije, Demetra, Zagreb.

Luhmann, Niklas (1982), Die Funktion der Religion, Suhrkamp, Frankfurt.

Luhmann, Niklas (2000), Die Religion der Gesellschaft, ur. André Kieserling, Suhrkamp, Frankfurt.

Markešić, Ivan (2015), Rideo ergo sum (Smijem se, dakle postojim). Uvodni tekst za knjigu "Fratri bosanski u stripu. Na svoj račun - na svoj način", Prometej, 17. 3. 2015. Dostupno na: http://www.prometej.ba/clanak/kultura/rideo-ergo-sum-smijem-se-daklepostojim-1935.

Pollack, Detlef (1998), Einleitung. Religiöser Wandel in Mittel- und Osteuropa. U: Detlef Pollack - Irena Borowik - Wolfgang Jagodzinski (ur.) Religiöser Wandel in den postkommunistischen Ländern Ost- und Mitteleuropas, Ergon Verlag, Würzburg.

Treibel, Annette (2008), Norbert Elias - Stationen der Biografie und der Rezeption. U: Treibel, Annette Die Soziologie von Norbert Elias. Eine Einführung in ihre Geschichte, Systematik und Perspektiven, VS Verlag für Sozialwissenschaften / GWV Fachverlage GmbH, Wiesbaden.

Vuković, Tomislav (2018), Stvaranje zločinca, Svjetlo riječi, veljača 2018, str. 54-55. Dostupno na:http://www.svjetlorijeci.ba/novosti/stvaranje-\%E2\%80\%9Ezlo $\% C 4 \% 8$ Dinca $\%$ E2\% 80\%9D-stepinca, pristupljeno 12. 1. 2020. 
Doprinos akademika Ivana Cvitkovića razvoju sociologije religije (Povodom 75. godišnjice života)

Weber, Max (1989a), Die Wirtschaftsethik der Weltreligionen, 1915-1921, Gesammelte Aufsätze zur Religionssoziologie I, Tübingen.

Weber, Max (1989b), Protestantska etika i duh kapitalizma, 2. izd., Veselin Masleša / Svjetlost, Sarajevo. 